\title{
Identification of Genes Involved in the Response of Banana to Crown Rot Disease
}

\author{
Ludivine Lassois, ${ }^{1}$ Patrick Frettinger, ${ }^{2}$ Luc de Lapeyre de Bellaire, ${ }^{3,4}$ Philippe Lepoivre, ${ }^{1}$ and \\ Haissam Jijakli'
}

\begin{abstract}
1 University of Liege, Gembloux Agro-Bio Tech, Plant Pathology Unit. Passage des Déportés 2, B-5030 Gembloux, Belgium; ${ }^{2}$ Unité Mixte de Recherches INRA-CNRS-Université de Bourgogne, Plante-Microbe Environnement, INRA, 17 Rue Sully, BP 86510, 21065 Dijon cedex, France; ${ }^{3}$ CIRAD, Persyst, UPR Syst. Banan. Ananas, TA B-26 / PS4, Blvd. de la Lironde, 34398 Montpellier Cedex 5, France; ${ }^{4}$ CARBAP, African Center for Research on Bananas and Plantains, Nyombé, Cameroon
\end{abstract}

Submitted 4 March 2010. Accepted 25 August 2010.

Variations in banana susceptibility to crown rot disease have been observed but the molecular mechanisms underlying these quantitative host-pathogen relationships are still unknown. This study was designed to compare gene expression between crowns of banana fruit showing a high susceptibility $\left(\mathrm{S}^{+}\right)$and crowns showing a low susceptibility $\left(S^{-}\right)$to the disease. Comparisons were performed at two situation times: $i)$ between crowns $\left(S^{+}\right.$and $\left.S^{-}\right)$collected $1 \mathrm{~h}$ before inoculation and ii) between crowns $\left(\mathrm{S}^{+}\right.$and $\left.\mathrm{S}^{-}\right)$collected 13 days after inoculation. Gene expression comparisons were performed with cDNA-amplified fragment length polymorphism (AFLP) and results were confirmed by realtime reverse-transcription polymerase chain reaction. Among genes identified as differentially expressed between $S^{+}$and $S^{-}$crowns, two were involved in signal transduction, three in proteolytic machinery, two had similarity to pathogenesis-related protein 14, one to a CCR4-associated factor protein, and one to a cellulose synthase. Paradoxically, the overexpression of the cellulose synthase gene was associated with banana showing a high susceptibility in both preand post-inoculation situations. Finally, the cDNA-AFLP identified a gene that seems to be associated with the quantitative banana responses to crown rot disease; this gene encodes a dopamine- $\beta$-monooxygenase, which is involved in the catecholamine pathway. To our knowledge, this work is the first to address both pre- and post-infection gene expression with the same host-pathogen combination and distinct susceptibility levels.

Crown rot disease affects export banana fruit in all producing countries and is considered to be one of the main postharvest diseases of banana (Lassois et al. 2010b). The symptoms appear on the crown (i.e., the tissue joining the fruit pedicels with each other). The disease develops during shipping, ripening, and storage and has a negative impact on the market value of banana fruit (Slabaugh and Grove 1982).

Variations, notably geographic and seasonal, have been reported in the postharvest development of crown rot disease

Corresponding author: L. Lassois; E-mail: ludivine.lassois@ulg.ac.be

* The $\boldsymbol{e}$-Xtra logo stands for "electronic extra" and indicates that Figure 3 appears in color online and a supplementary table is published online.

This article is in the public domain and not copyrightable. It may be freely reprinted with customary crediting of the source. The American Phytopathological Society, 2010. symptoms (Krauss and Johanson 2000; Lassois et al. 2008; Lukezic et al. 1967; Shillingford 1978). It has been suggested that these spatiotemporal fluctuations reflect the variations in the banana fruit quality potential that elaborates during preharvest stages (Lassois et al. 2010b). This quality potential depends on both physiological and parasitic components which, in turn, are influenced by agrotechnical and soil-climate factors. The parasitic component reflects the level of crown contamination by the parasitic complex, as well as the pathogenicity of this parasitic complex. Effectively, crown rot results from an unspecific parasitic complex from which Colletotrichum musae is the most pathogenic species (Finlay and Brown 1993). The term "physiological component" refers here to the level of fruit susceptibility to crown rot. To assess the level of fruit susceptibility, it is necessary to overcome the influence of the parasitic component. It is then estimated through lesion size after standardized artificial inoculations with C. musae (de Lapeyre de Bellaire et al. 2008). Very few studies have linked the spatiotemporal fluctuations of crown rot disease to preharvest factors influencing the level of fruit susceptibility (Lassois et al. 2008). Nevertheless, it has been shown recently that the source/sink ratio and the hand position in the bunch affect the banana susceptibility to crown rot disease (Lassois et al. 2010a). The genetic and molecular mechanisms underlying these quantitative host-pathogen relationships have not been identified.

Plant defense mechanisms to diseases are mediated by both preformed and inducible responses which lead to significant transcriptional changes in the host (Lucas 1998). One way to understand the reactions involved in the variation of banana responses to crown rot is then to identify genes involved in these processes via the study of their expression. The cDNAamplified fragment length polymorphism (AFLP) technique (Bachem 1996) has been used to compare genome-wide expression patterns and to identify differentially expressed genes potentially related to plant defense mechanisms. This technique does not require prior knowledge of defense mechanisms to identify new genes. Thus, it can be used for any biological system, especially when genomic resources are lacking. In addition, the mechanisms responsible for compatibility interactions and for the quantitative variation of symptoms after infection remain poorly understood, and it is likely that some of the factors involved remain to be discovered. The sensitivity and specificity of cDNA-AFLP analysis are comparable with those of a microarray approach (Reijans et al. 2003). Its reproducibility has also been proven (Kuhn 2001; Lassois et al. 2009).

The present study was designed to identify genes influencing the susceptibility to crown rot disease at distinct physiological 
stages and in the same banana cultivar. A cDNA-AFLP technique was used to compare gene expression in banana crowns from plants (Musa acuminata, AAA, cv. Grande-Naine) showing different susceptibility to crown rot disease. In this study, the variation of source/sink ratio previously described (Lassois et al. 2010a) has been used to obtain banana plants showing different susceptibility to crown rot disease. Samples were collected before and after infection. The differential expression deduced from cDNA-AFLP data was then confirmed by an independent technique, real-time reverse-transcription polymerase chain reaction (RT-PCR). This latter technique was quick and, thanks to its high sensitivity, required only a small amount of starting material (Massart and Jijakli 2006).

\section{RESULTS}

\section{Banana samples.}

As expected, by modification of the source/sink ratio at flowering, we were able to obtain banana plants with different susceptibility levels. Crowns obtained from the two 12-leaf and two-hand banana plants had average internal necrotic surface (INS) values of 123 and $168 \mathrm{~mm}^{2}$ (Fig. 1), indicating that they were less susceptible (low-susceptibility $\left[\mathrm{S}^{-}\right]$plants) to crown rot disease than the crowns obtained from both 12 leaf/eight-hand banana plants (INS values of 369 and $395 \mathrm{~mm}^{2}$ ) (high-susceptibility $\left[\mathrm{S}^{+}\right]$plants). RNA was successfully extracted from all eight freeze-dried crown samples (results not shown).

\section{Isolation of differently expressed genes.}

The cDNA pools from $\mathrm{S}^{-}$plant 1 (less susceptible to crown rot) and $\mathrm{S}^{+}$plant 1 (more susceptible) at both collection times were subjected to cDNA-AFLP screening. In total, eight com- binations of EcoRI+2/MseI+2 primers were used and more than 3,100 bands were amplified from the cDNA pools. The cDNA-AFLP technique revealed 157 amplicons (i.e., approximately $10 \%$ of the total amplicons on the corresponding profile) that were differentially expressed between the high- and low-susceptibility $\left(\mathrm{S}^{+}\right.$and $\mathrm{S}^{-}$, respectively) samples collected $1 \mathrm{~h}$ before inoculation (1 hbi); these banana fruit had not been treated with ethrel. In contrast, 286 amplicons (approximately $14 \%$ of the total amplicons) were differentially expressed between the $\mathrm{S}^{+}$and $\mathrm{S}^{-}$samples collected 13 days postinoculation (13 dpi); these banana fruit had been treated with ethrel (Table 1 ). Only bands showing a clear intensity difference between $S^{+}$ and $\mathrm{S}^{-}$upon visual inspection, without other bands nearby (Fig. 2) were excised from the polyacrylamide gels, cloned, and sequenced.

In all, 32 and 99 transcript derived fragments (TDF) were selected from samples collected $1 \mathrm{hbi}$ and $13 \mathrm{dpi}$, respectively. Among them, 16 (for $1 \mathrm{hbi}$ ) and 62 (for $13 \mathrm{dpi}$ ) were successfully recovered from the gels, reamplified, cloned, and sequenced (Table 1). These 78 distinct nucleotide sequences were then subjected to a BlastX homology search. This analysis revealed nonredundant significant homology with plant gene sequences in the public database for 15 of the 16 selected TDF from the 1-hbi profile (Table 2) and 31 of the 62 TDF selected from the 13-dpi profile (Table 2). The remaining $31 \mathrm{TDF}$ from the 13-dpi profile showed no significant homology to any known plant sequence.

\section{Confirmation of differently expressed fragments by real- time RT-PCR.}

All TDF from Table 2, for which specific primer pairs were successfully designed, were selected for confirmation of their differential expression by real time RT-PCR. Here, cDNA pools

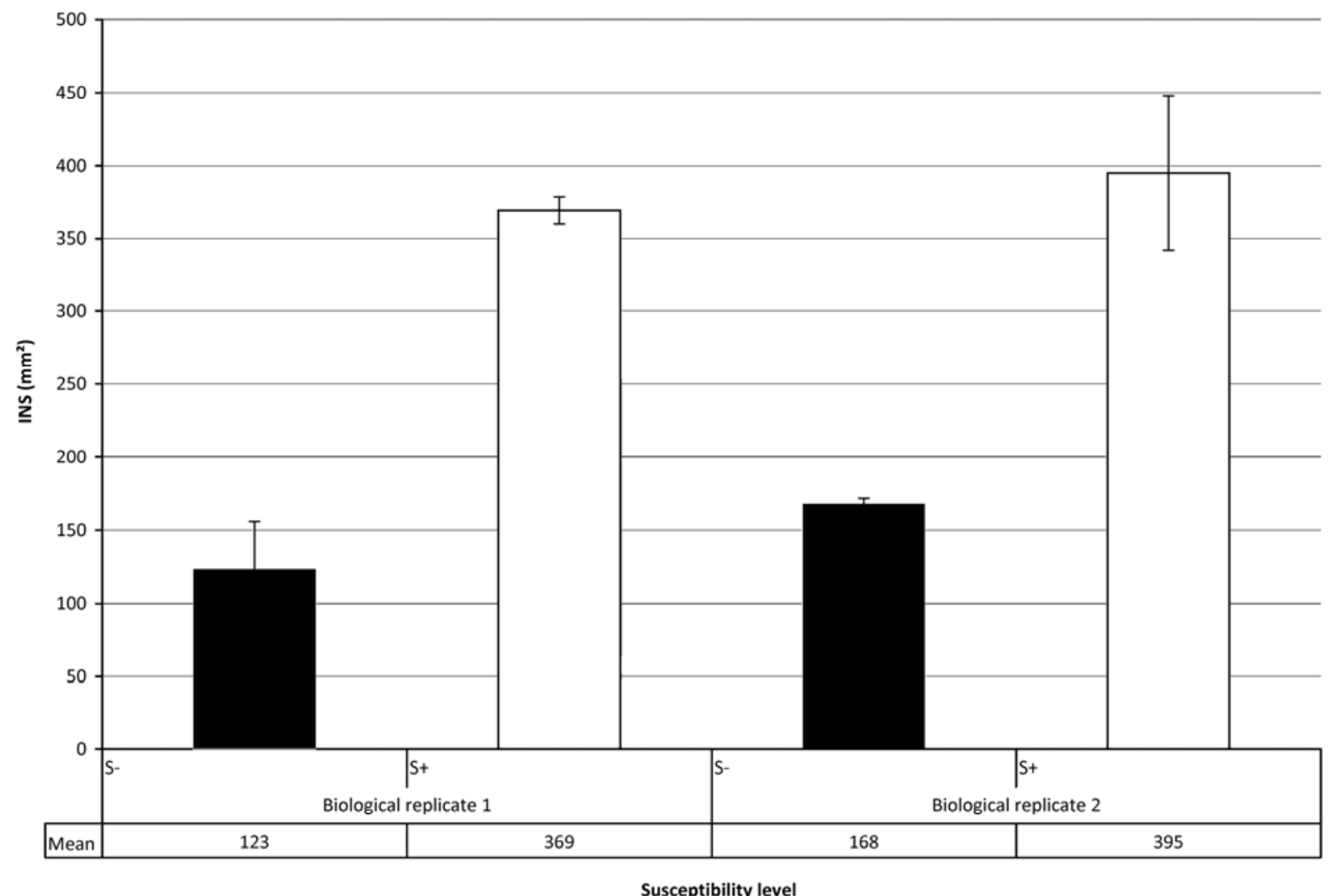

Fig. 1. Susceptibility of the banana crowns used for molecular analyses, as determined by measuring the internal necrotic surface (INS, expressed in square millimeters). INS average and standard deviation of the three clusters of the same second hand are given for the two independent biological replicates and for the two different susceptibility level banana plants. 
from all four plants were used, providing two independent biological replicates.

\section{TDF isolated 1 hbi}

Primer pairs were successfully designed, amplifying the expected products for only 7 of the 15 TDF (Supplementary Table 1). The real-time RT-PCR results for biological replicate 1 (material from $\mathrm{S}^{+}$plant 1 and $\mathrm{S}^{-}$plant 1 ) confirmed the changes in expression in all of the seven tested TDF (Table 2). Only one TDF (48.1), which encoded a hypothetical protein, did not show the same regulation in the biological replicate 2 (Table 2). The six TDF that had the same pattern of expression for the two biological replicates were found to encode proteins showing similarity to a putative protein kinase (48b.1), a protein of the dual-specificity protein phosphatase family (44b.2), a protein of the RING-type ubiquitin ligase family (31.1), a dopamine- $\beta$-monooxygenase (33.2), a hypothetical protein (44.1), and a glycolipid transfer protein (47.1) (Table 2). The six corresponding primer combinations were also used in realtime RT-PCR experiments on the cDNA pools obtained from the samples collected $13 \mathrm{dpi}$ from all four plants (Table 3 ). The putative protein kinase and the dopamine- $\beta$-monooxygenase appeared upregulated in the $\mathrm{S}^{-}$tissues collected $1 \mathrm{hbi}$, becoming highly upregulated in the tissues collected 13 dpi. The member of the dual-specificity phosphatase family, the RINGtype ubiquitin ligase family, and the glycolipid transfer protein appeared downregulated in the $\mathrm{S}^{-}$tissues collected 1 hbi but highly upregulated in the $\mathrm{S}^{-}$tissues collected $13 \mathrm{dpi}$. The last protein, a hypothetical one, showed strong downregulation in the tissues collected at both times (Table 3 ).

\section{TDF isolated 13 dpi.}

In all, 21 primer pairs amplified the expected products. Among the corresponding $21 \mathrm{TDF}$, only 5 had the same pattern of expression in both real-time RT-PCR biological replicates (Table 2). They were found to encode proteins showing similarity to a cellulose synthase (294.2), a putative glycolipid transfer protein (283.1), a serine carboxypeptidase (232.2), a putative ubiquitin carboxyl-terminal hydrolase (317.1), and a protein related to the CCR4-associated factor 1 (190.2) (Table 2). The five corresponding primer combinations were also used in real-time RT-PCR experiments performed on the cDNA pools derived from samples collected 1 hbi from all four plants (Ta- ble 3). Serine caroboxypeptidase appeared upregulated in $\mathrm{S}^{-}$ tissues collected $1 \mathrm{hbi}$ and slightly more so in tissues collected 13 dpi. Cellulose synthase showed similar downregulation in $\mathrm{S}^{-}$tissues collected $1 \mathrm{hbi}$ and $13 \mathrm{dpi}$. The putative glycolipid transfer protein appeared downregulated in $\mathrm{S}^{-}$tissues collected $1 \mathrm{hbi}$, becoming highly upregulated by $13 \mathrm{dpi}$. For both the putative ubiquitin carboxyterminal hydrolase and the protein related to CCR4-associated factor 1 , the biological duplicates showed similar results for $13 \mathrm{dpi}$ (upregulation in $\mathrm{S}^{-}$tissues) but different results for $1 \mathrm{hbi}$ : slight downregulation in tissues from $\mathrm{S}^{-}$plant 1 but slight upregulation in tissues from $\mathrm{S}^{-}$plant 2.

\section{DISCUSSION}

Transcriptome analysis is a common way of discovering differences in gene expression between two samples because regulation of gene activity occurs primarily at the transcriptional level. cDNA-AFLP has the advantage of being an openended method that requires only standard instrumentation at a low cost but has the disadvantage of missing many differentially expressed genes. Indeed, although, in theory, the cDNAAFLP technique allows analysis of the whole transcriptome, in practice, the estimated transcriptome coverage ranges from less than 20 to $73 \%$ (Venkatesh et al. 2005). Reasons for this low coverage are i) the lack of suitable restriction sites (Breyne et al. 2003), ii) the subjectivity of band selection, and iii) the intensive labor and time, including selection at multiple steps. Furthermore, in the present study, we focused only on fragments sharing sequence similarity with known genes, amounting to only $60 \%$ of our fragments. Similar or lower percentages are reported in the literature for cDNA-AFLP (Botton et al. 2008; Chen et al. 2003; Dilger et al. 2003; Dong et al. 2004; Guo et al. 2006; Trindade et al. 2004).. Results obtained in this study provide a supplementary proof of the escaping detection. Indeed, different genes (differentially expressed between $\mathrm{S}^{+}$and $\mathrm{S}^{-}$) were put in evidence between $1 \mathrm{hbi}$ and 13 dpi detection while the real-time RT-PCR shows that these genes were differently expressed in both stages. For example, 33.2 (Table 3) was identified by cDNA-AFLP in a 1-hbi and not 13-dpi sample while RT-PCR showed that 33.2 was also differentially expressed in a 13-dpi sample. Thus, it is essential to bear in mind that some interesting genes involved in the banana response to crown rot disease might not have been identified in our study.

Table 1. Overall results of cDNA-amplified fragment length polymorphism (AFLP) analysis (with eight primer combinations) and real-time reversetranscription polymerase chain reaction (RT-PCR) confirmation

\begin{tabular}{lr}
\hline Expression profile & Number \\
\hline Material harvested 1 h before inoculation & 822 and 683 \\
cDNA fragments displayed (100 to 450 bp) in low-susceptibility $\left(\mathrm{S}^{-}\right)$and high-susceptibility $\left(\mathrm{S}^{+}\right)$fruit & 157 \\
Differently expressed fragments & 62 \\
Upregulated in S $^{-}$ & 95 \\
Downregulated in S & 32 \\
Transcript derived fragments (TDF) selected and excised & 16 \\
TDF successfully recovered from the gels, reamplified, cloned and sequenced & 15 \\
Non redundant significant similarities with the database after analysis & 7 \\
Selected TDF for real time RT-PCR confirmation & 7 \\
cDNA-AFLP result confirmation by real time RT-PCR/ Biological replicate 1 & 6 \\
cDNA-AFLP result confirmation by real time RT-PCR/ Biological replicate 2 & \\
Material harvested 13 days postinoculation & 811 and 845 \\
cDNA fragments displayed (100 to 450 bp) in S- and S ${ }^{+}$ & 286 \\
Differently expressed fragments & 166 \\
Upregulated in S & 120 \\
Downregulated in S- & 99 \\
TDF selected and excised & 62 \\
TDF successully recovered from the gels, reamplified, cloned and sequenced & 31 \\
Nonredundant significant similarities with the database after analysis & 21 \\
Selected TDF for real time RT-PCR confirmation & \\
cDNA-AFLP result confirmation by real time RT-PCR/ Biological replicate 1 & 17 \\
cDNA-AFLP result confirmation by real time RT-PCR/ Biological replicate 2 & 5 \\
\hline
\end{tabular}


This study also highlights the importance of confirming results with an independent technique. In the runs performed on material derived from $\mathrm{S}^{+}$plant 1 and $\mathrm{S}^{-}$plant 1 (the same material as used for cDNA-AFLP analysis), the real-time RTPCR confirmed the differential expression for $86 \%$ of the cDNA-AFLP fragments. Nonconfirmation is likely due to the fact that a band in a gel can contain a mixture of several fragments (Chen et al. 2006; Hsu et al. 2008; Zhang 2003). This introduces artefactual cloning (Bachem et al. 1998) and can also lead to misinterpretation (overestimation) of cDNA-AFLP fragment expression levels in the gel. In the literature, investigators report confirmation rates of $30 \%$ (Campalans et al. 2001; Fukuda et al. 1999) to $100 \%$ (Ditt et al. 2001) for genes

\section{Eco RI+cc/Mse I+ag}

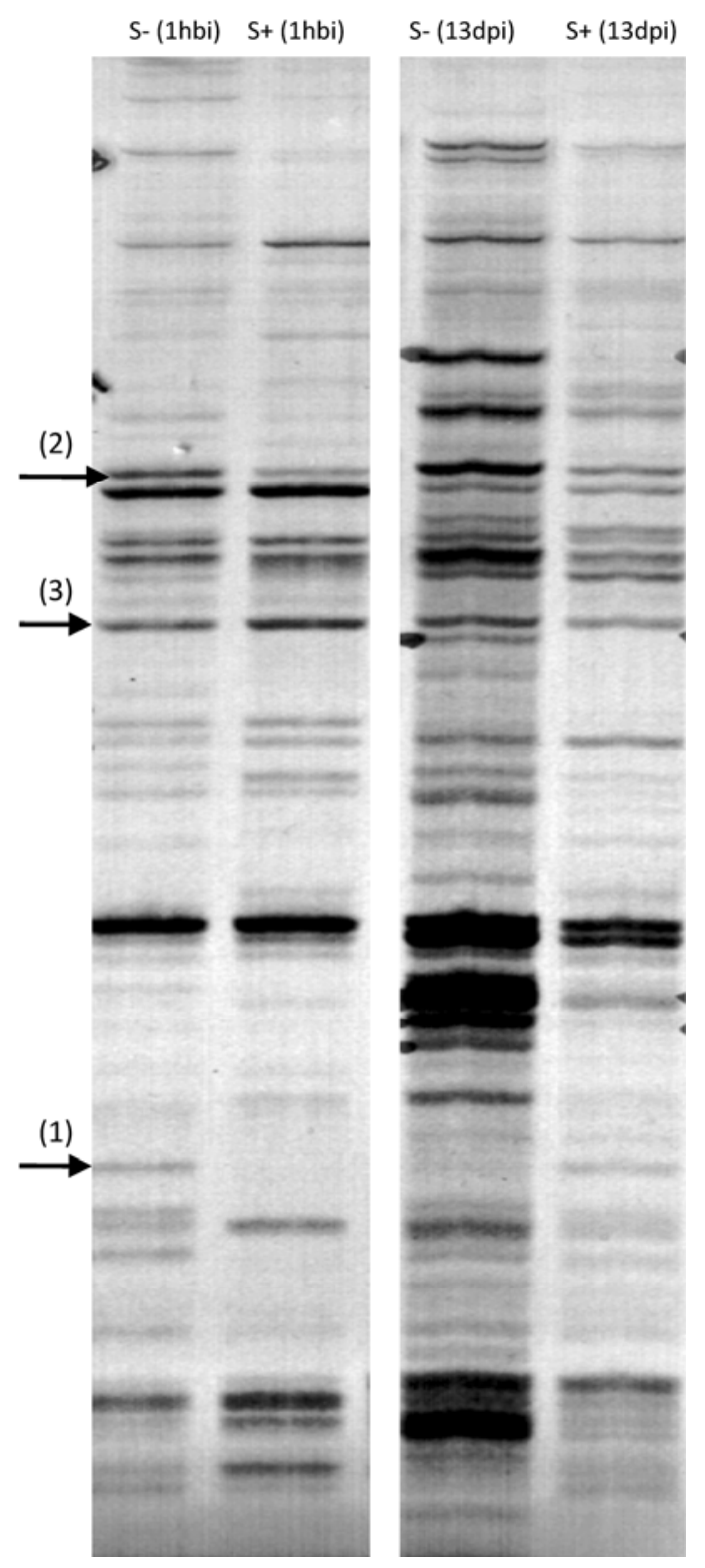

Fig. 2. Autoradiography showing a typical result for one selective EcoRI/ MseI primer combination for comparing high-susceptibility $\left(\mathrm{S}^{+}\right)$banana tissues with low-susceptibility $\left(\mathrm{S}^{-}\right)$banana tissues at two times: $1 \mathrm{~h}$ before inoculation ( $1 \mathrm{hbi}$ ) and 13 days postinoculation (13 dpi). Arrows indicate examples of: (1) a transcripts of an induced gene; (2) transcripts of an upregulated gene; and (3) transcripts of an unaffected gene. Differentially expressed transcript-derived fragments (TDF) were excised from the gel, reamplified, cloned, and sequenced. identified by cDNA-AFLP analysis and tested with an independent technique. Moreover, our results also demonstrate the necessity of confirming results with biological replicates before concluding that a gene is involved in a molecular process, because the initial differential expression was confirmed in both biological replicates for only $46 \%$ of our selected genes.

Despite these limitations, the cDNA-AFLP technique has provided useful information about the possible mechanisms underlying variation in banana susceptibility to crown rot disease; this is the first study addressing this in this pathosystem. Because of the compatibility of the interaction, we expected significant transcriptional changes to occur among genes associated with cellular changes involved in general defense responses. It was no surprise to find genes involved in signal transduction or proteolytic pathways among those potentially involved in banana defense responses. It is well known that these pathways are complex but required to regulate defense responses, even though the exact regulatory mechanisms are not yet known.

The sequences encoded by fragments $48 \mathrm{~b} .1$ and $44 \mathrm{~b} .2$ show homology with a putative protein kinase and a protein of the dual specificity phosphatase family, respectively. Proteins of both types catalyze reversible protein phosphorylations involved in signaling pathways. It is known that synthesis of such proteins is triggered by an array of stimuli and that they target a broad range of downstream effectors, thereby regulating various processes such as defense responses (Agrawal et al. 2002, 2003; Lecourieux-Quaked et al. 2000; Nurnberger et al. 2004; Rakwal et al. 2001).

The proteins corresponding to fragments 31.1 (a RING-type ubiquitin ligase) and 317.1 (a putative ubiquitin carboxyl-terminal hydrolase) belong to the proteolytic machinery that plays key roles in the regulation of biological processes in plants (Edelmann and Kessler 2008), including ones mediating responses to pathogens (Devoto et al. 2003; Ellis et al. 2002; van der Hoorn and Jones 2004; Zeng et al. 2006). More specifically, proteins of this type are involved in the $26 \mathrm{~S}$ proteasome pathway, considered to be the main proteolytic pathway in eukaryotes. In recent years, approximately a dozen ubiquitinylation-related components have been identified as being involved in plant-pathogen interactions (Zeng et al. 2006) but, in most cases, the exact nature of the regulation is not known. Most proteins of this type are induced in response to pathogen or elicitor challenges (Boyes et al. 1998; Ramonell et al. 2005; Salinas-Mondragón et al. 1999; Serrano and Guzman 2004; Takizawa et al. 2005; Zeng et al. 2006).

In addition to the $26 \mathrm{~S}$ proteasome pathway, there are other proteases that may be involved in plant defense (Avrova et al. 1999; Kruger et al. 2002; Pautot et al. 1993; Tornero et al. 1996; Xia et al. 2004). Serine carboxypeptidase (232.2) is a protease with a well-established function in protein turnover for the mobilization of N-resources, notably during seed germination (Dal Degan et al. 1994; Granat et al. 2003) and wound stress (Moura et al. 2001). Our results suggest that serine carboxypeptidase could be also involved in the plant-pathogen response. This protein appears to be upregulated in $\mathrm{S}^{-}$crown both pre- and post-infection but to a lesser extent at $1 \mathrm{hbi}$.

The proteins corresponding to fragments 47.1 and 283.1 show high similarity to glycolipid transfer protein type 1 of Arabidopsis thaliana (AtGLTP1). They belong to the lipidtransfer protein 1 (LTP1) family, classified as pathogenesisrelated (PR) family 14 (PR-14). Such proteins can be activated by elicitation and accumulate in plants, mounting a defensive response against pathogens, including fungi (Van Loon et al. 2006). Yet the precise role of LTP in defense responses remains to be discovered. AtGLTP1 has been shown in vitro to enhance the intervesicular trafficking of glycosphingolipids but the precise in vivo biological function is still unknown 
(Brown and Mattjus 2007). Both banana genes showed the same regulation profile: slightly lower expression in $\mathrm{S}^{-}$than in $\mathrm{S}^{+}$crown tissue before pathogen inoculation and much higher expression in the former than in the latter $13 \mathrm{dpi}$.
On the other hand, cDNA-AFLP provided clues that may contribute to understanding the mechanisms involved in banana responses to crown rot disease. One is CCR4-associated factor 1 (CAF1). CAF1 proteins are required for regulated dea-

Table 2. BlastX identities of nonredundant clones ${ }^{\mathrm{a}}$ and the number of cases in which differential expression was confirmed by real-time reverse-transcription polymerase chain reaction (RT-PCR) (two independent biological replicates)

\begin{tabular}{|c|c|c|c|c|c|c|c|c|c|}
\hline $\begin{array}{l}\text { GenBank } \\
\text { accession } \\
\text { nos. }\end{array}$ & Fragment & $\begin{array}{l}\text { Size } \\
\text { (bp) }\end{array}$ & AFLP $\mathbf{P}^{\mathbf{b}}$ & Homology & Annotation & Organism origin & $\begin{array}{c}\text { E-value } \\
\text { (similarity } \\
[\%])\end{array}$ & BR1 ${ }^{c}$ & $\mathbf{B R 2}^{\mathbf{c}}$ \\
\hline \multicolumn{10}{|l|}{1 hbi } \\
\hline HO058947.1 & $48 b .1$ & 447 & + & ABF71990 & Putative protein kinase & Musa acuminata & $8 e-29(82)$ & Yes & Yes \\
\hline HO058948.1 & $44 \mathrm{~b} .2$ & 620 & - & ABF70116 & $\begin{array}{l}\text { Dual-specificity protein phosphatase } \\
\text { family protein }\end{array}$ & M. balbisiana & $2 \mathrm{e}-18(57)$ & Yes & Yes \\
\hline HO058949.1 & 31.1 & 411 & - & NP_195309 & RING-type ubiquitin ligase & Arabidopsis thaliana & $8 \mathrm{e}-21(79)$ & Yes & Yes \\
\hline HO058950.1 & 33.2 & 348 & + & EEF-29330 & Dopamine- $\beta$-monooxygenase & Ricinus communis & $5 e-34(74)$ & Yes & Yes \\
\hline HO058951.1 & 44.1 & 607 & - & NP_001053150 & Hypothetical protein & Oryza sativa & $5 e-65(87)$ & Yes & Yes \\
\hline HO058952.1 & 47.1 & 490 & - & NP_565766 & Glycolip transfer protein & A. thaliana & $7 e-39(87)$ & Yes & Yes \\
\hline HO058953.1 & 48.1 & 454 & - & CAN81047 & Hypothetical protein & Vitis vinifera & $6 e-65(91)$ & Yes & No \\
\hline HO058954.1 & 73.1 & 245 & - & CAO60899 & Hypothetical protein & $V$. vinifera & $3 e-06(61)$ & ND & ND \\
\hline HO058955.1 & 73.2 & 248 & - & CAN81194 & Hypothetical protein & $V$. vinifera & $7 e-33(98)$ & ND & ND \\
\hline HO058956.1 & 32.1 & 402 & + & NP_187791 & Unknown protein & A. thaliana & $1 e-20(68)$ & ND & ND \\
\hline HO058957.1 & 36.1 & 193 & - & NP_001060105 & Hypothetical protein & O. sativa & $6 e-19(85)$ & ND & ND \\
\hline HO058958.1 & 37.1 & 186 & - & EEC73391 & Hypothetical protein & O. sativa & $2 \mathrm{e}-16(80)$ & ND & ND \\
\hline HO058959.1 & $51 b .1$ & 366 & - & NP_001055242 & Hypothetical protein & O. sativa & $9 e-15(56)$ & ND & ND \\
\hline HO058960.1 & 70.2 & 426 & - & CAN- 66568.1| & Hypothetical protein & $V$. vinifera & $3 e-14(65)$ & ND & ND \\
\hline HO058961.1 & 5.2 & 282 & + & EEE54897 & Hypothetical protein & O. sativa & $7 e-07(54)$ & ND & ND \\
\hline \multicolumn{10}{|l|}{13 dpi } \\
\hline HO058962.1 & 294.2 & 298 & + & NP_001104954 & Cellulose synthase & Zea mays & $3 e-43(96)$ & Yes & Yes \\
\hline HO058963.1 & 283.1 & 444 & + & EEF32539 & Putative glycolipid transfer protein & R. communis & $4 \mathrm{e}-20(92)$ & Yes & Yes \\
\hline HO058964.1 & 232.2 & 119 & + & ACG29071 & Serine carboxypeptidase II-3 & Z. mays & $1 \mathrm{e}-12(89)$ & Yes & Yes \\
\hline HO058965.1 & 317.1 & 425 & - & EEF47930 & $\begin{array}{l}\text { Putative ubiquitin carboxyl-terminal } \\
\text { hydrolase }\end{array}$ & R. communis & $3 e-52(78)$ & Yes & Yes \\
\hline HO058966.1 & 190.2 & 618 & + & ABG66307 & $\begin{array}{l}\text { CCR4 associated factor 1-related } \\
\text { protein }\end{array}$ & Capsicum аппиит & $1 \mathrm{e}-58(77)$ & Yes & Yes \\
\hline HO058967.1 & 284.1 & 434 & - & EEF44770 & Putative lactoylglutathione lyase & R. communis & $5 e-28(84)$ & Yes & No \\
\hline HO058968.1 & 197.2 & 418 & + & AAF23074 & Heat shock protein 70 & Triticum aestivum & $6 e-53(99)$ & Yes & No \\
\hline HO058969.1 & 145.2 & 298 & - & EEF32493 & $\begin{array}{l}\text { Putative ribose-5-phosphate } \\
\text { isomerase }\end{array}$ & R. communis & $1 \mathrm{e}-10(81)$ & Yes & No \\
\hline HO058970.1 & 220.2 & 390 & + & EEF37576 & Putative sulfate transporter & R. communis & $1 \mathrm{e}-27(86)$ & Yes & No \\
\hline HO058971.1 & 220.3 & 395 & + & BAE99290 & $\begin{array}{l}\beta \text { - } N \text {-acetylhexosaminidase-like } \\
\text { protein }\end{array}$ & A. thaliana & $2 \mathrm{e}-59(90)$ & Yes & No \\
\hline HO058972.1 & 178.1 & 270 & + & A2XDD6 & $\begin{array}{l}\text { Homeobox-leucine zipper protein } \\
\text { HOX13 }\end{array}$ & O. sativa & $9 e-12(64)$ & Yes & No \\
\hline HO058973.1 & 233.2 & 129 & + & ABC72694 & Granule-bound starch synthase & Cephalostachyum mannii & $3 e-12(97)$ & Yes & No \\
\hline HO058974.1 & 231.3 & 147 & + & NP_195906 & $\begin{array}{l}\text { Pentatricopeptide (PPR) repeat- } \\
\text { containing protein }\end{array}$ & A. thaliana & $3 e-09(82)$ & Yes & No \\
\hline HO058975.1 & 241.1 & 458 & + & AAL59042 & $\begin{array}{l}\text { Putative tetratricopeptide repeat } \\
\text { protein }\end{array}$ & O. sativa & $5 e-45(86)$ & Yes & No \\
\hline HO058976.1 & 243.2 & 343 & + & BAD30585 & $\begin{array}{l}\text { Putative 2-amino-4-hydroxy-6- } \\
\text { hydroxymethyldihydropteridine } \\
\text { diphosphokinase }\end{array}$ & O. sativa & $3 e-31(83)$ & Yes & No \\
\hline HO058977.1 & 291.2 & 348 & + & EEC70392 & Hypothetical protein & O. sativa & $6 e-27(73)$ & Yes & No \\
\hline HO058978.1 & 216.1 & 466 & + & AAX07420 & Actin 2 & M. acuminata & $1 e-74(98)$ & Yes & No \\
\hline HO058979.1 & 198.1 & 291 & + & ACG32616 & expp1 Protein precursor & Z. mays & $1 \mathrm{e}-25(84)$ & No & $\ldots$ \\
\hline HO058980.1 & 170.2 & 405 & + & ABF98518 & Putative protein kinase & O. sativa & $3 e-59(89)$ & No & $\ldots$ \\
\hline HO058981.1 & 182.2 & 169 & - & AAO43609 & Caffeic acid O-methyltransferase & Sorghum bicolor & $2 \mathrm{e}-09(76)$ & No & $\ldots$ \\
\hline HO058982.1 & 288.1 & 357 & + & Q9XF47 & Cytosolic fructose 1,6 biphosphatase & M. acuminata & $4 \mathrm{e}-42(97)$ & No & $\ldots$ \\
\hline HO058983.1 & 285.1 & 417 & + & Q0JDM0 & $\begin{array}{l}\text { Zinc-finger CCCH domain- } \\
\text { containing protein } 27\end{array}$ & O. sativa & $9 \mathrm{e}-41(81)$ & ND & ND \\
\hline HO058984.1 & 283.2 & 448 & - & ACG28752 & Serine/threonine-protein kinase NAK & Z. mays & $1 \mathrm{e}-46(81)$ & ND & ND \\
\hline HO058985.1 & 183.1 & 170 & + & CAN60313 & $\begin{array}{l}\text { Putative serine/threonine protein } \\
\text { kinase }\end{array}$ & V. vinifera & $5 e-13(79)$ & ND & ND \\
\hline HO058986.1 & 182.1 & 167 & - & EEF50185 & $\begin{array}{l}\text { Putative serine/threonine protein } \\
\text { kinase }\end{array}$ & R. communis & $4 e-14(80)$ & ND & ND \\
\hline HO058987.1 & 302.1 & 205 & - & CAO46913 & Unnamed protein product & V. vinifera & $2 \mathrm{e}-09(89)$ & ND & ND \\
\hline HO058988.1 & 143.1 & 334 & + & $\mathrm{CAO} 45614$ & Unnamed protein product & $V$. vinifera & $1 \mathrm{e}-31(88)$ & ND & ND \\
\hline HO058989.1 & 318.2 & 419 & + & CAO66159 & Unnamed protein product & $V$. vinifera & $3 e-38(82)$ & ND & ND \\
\hline HO058990.1 & 312.2 & 120 & - & CAN71825 & Hypothetical protein & $V$. vinifera & $7 e-10(88)$ & ND & ND \\
\hline HO058991.1 & 290.1 & 361 & - & EEE60281 & Hypothetical protein & O. sativa & $8 e-32(74)$ & ND & ND \\
\hline HO058992.1 & 171.1 & 373 & + & CAN72176 & Hypothetical protein & $V$. vinifera & $5 e-37(82)$ & ND & ND \\
\hline
\end{tabular}

a Identified by comparing the cDNA-amplified fragment length polymorphism (AFLP) profiles of highly susceptible and less susceptible banana crown tissues collected $1 \mathrm{~h}$ before inoculation $(1 \mathrm{hbi})$ and 13 days postinoculation $(13 \mathrm{dpi})$.

${ }^{\mathrm{b}}$ cDNA-AFLP regulation $\mathrm{S}^{-} ;+$means upregulation in $\mathrm{S}^{-}$compared with $\mathrm{S}^{+}$crown tissue and - means downregulation in $\mathrm{S}^{-}$compared with $\mathrm{S}^{+}$crown tissue.

${ }^{c}$ Real-time RT-PCR confirmation for biological replicates 1 and 2 (BR1 and BR2, respectively). ND = not done. 
denylation of a broad spectrum of stress-responsive mRNAs but the biochemical and physiological functions of CAF1 proteins are not clearly established (Liang et al. 2009). They have been implicated in the regulation of plant growth (Sarowar et al. 2007) and defense responses to biotic (Lee et al. 2004; Liang et al. 2009; Sarowar et al. 2007) and abiotic stress (Liang et al. 2009; Walley et al. 2007). In our study, as in all known cases, CAF1 overexpression appears to result in enhanced resistance. No constitutive differential expression was noted prior to inoculation. Investigators have linked upregulation of multiple PR genes to overexpression of CAF1 genes (Liang et al. 2009; Sarowar et al. 2007). It will be interesting to study, in our model, the expression levels of some PR proteins in order to corroborate previous results and to attempt to better understand the role of CAF1 in resistance mechanisms.

Expression of the gene encoding a protein similar to cellulose synthase (294.2) is downregulated in $\mathrm{S}^{-}$banana crowns. This is somewhat surprising, because cellulose is a cell-wall component expected to play a role in forming a physical barrier against fungal penetration. Nevertheless, there is evidence that, when cellulose synthesis is reduced by mutation, lignin synthesis (CanoDelgado et al. 2003) and defense responses are activated through various signaling pathways (Cano-Delgado et al. 2003; Ellis et al. 2002). Here, we provide no information on lignin synthesis but we do show a correlation between reduced expression of the cellulose synthase gene and enhanced resistance.

Finally, cDNA-AFLP analysis has enabled us to identify a gene showing homology with a dopamine- $\beta$-monooxygenase (DoH) combined with a cytochrome B561 (CB) (33.2). DoH$\mathrm{CB}$ proteins form a recently identified group of proteins, likely to play a key role in catecholamine biosynthesis pathway in plants (Tsubaki et al. 2005; Verelst and Asard 2004). Dopa- mine hydroxylation by dopamine- $\beta$-monooxygenase leads to synthesis of norepinephrine, which is subsequently methylated to epinephrine. From a broad range of plants, banana fruit, and, particularly, Cavendish banana, have the richest content in cathecolamines and, particularly, in dopamine: $100 \mu \mathrm{g} / \mathrm{g} \mathrm{FW}$ in Cavendish banana peel compared with $7 \mu \mathrm{g} / \mathrm{g}$ FW for potato, the second richest plant of this list (Kulma and Szopa 2007). This observation suggests that cathecolamines might play an important role in banana physiology.

Various functions, including plant-pathogen resistance, have been proposed for catecholamines (Kulma and Szopa 2007; Swiedrych et al. 2004). Effects are probably due to the antioxidant properties of catecholamines themselves and also to cellwall deposition and the antioxidant properties of derivatives (Kulma and Szopa 2007). Whether catecholamines can stimulate some defense responses more directly remains to be seen (Kulma and Szopa 2007). However, catecholamine, dopamine, or oxidation products are suggested to be involved in banana resistance mechanisms (Mace 1963; Muirhead and Deverall 1984; Valette et al. 1998; Wuyts et al. 2006, 2007). Particularly, it has been shown that dopamine oxidation products have a brown-red color and show a strong antifungal activity against C. musae (Muirhead and Deverall 1984). It is noteworthy that the peripheral necrotic tissues observed here in the $\mathrm{S}^{-}$banana crowns showed a specific red-brown color (data not shown). Our results suggest that dopamine oxidation products might play an important role in susceptibility to crown rot disease.

It would be interesting to learn more about the role of dopamine- $\beta$-monooxygenase and other catecholamines in the response of banana to crown rot. We have shown that the dopamine- $\beta$-monooxygenase gene is overexpressed in banana less susceptible to the disease; however, we do not yet have informa-

Table 3. Genes differently expressed to a significant degree in $\mathrm{S}^{+}$and $\mathrm{S}^{-}$banana crown tissues and results of real-time reverse-transcription polymerase chain reaction (RT-PCR) confirmations of differential transcription (two biological replicates) ${ }^{\mathrm{a}}$

\begin{tabular}{|c|c|c|c|c|c|c|c|c|}
\hline \multirow{3}{*}{$\frac{\text { Isolation }^{c}}{1 \mathrm{hbi}}$} & \multirow{3}{*}{$\frac{\text { TDF }^{\mathbf{d}}}{48 \mathrm{~b} 1}$} & \multirow{3}{*}{$\frac{\text { Annotation }}{\text { Putative protein kinase }}$} & \multirow{2}{*}{\multicolumn{2}{|c|}{ GO biological process }} & & & \multicolumn{2}{|c|}{$\begin{array}{l}\text { Regulation } \\
\text { level }^{\mathbf{b}}\end{array}$} \\
\hline & & & & & \multicolumn{2}{|c|}{ GO molecular function } & 1 hbi & 13 dpi \\
\hline & & & GO: 0006468 & $\begin{array}{l}\text { Protein amino acid } \\
\text { phosphorylation }\end{array}$ & GO: 0004672 & Protein kinase activity & +2 & +4 \\
\hline $1 \mathrm{hbi}$ & $44 \mathrm{~b} 2$ & $\begin{array}{l}\text { Dual specificity phosphatase } \\
\text { family protein }\end{array}$ & GO: 0006470 & $\begin{array}{l}\text { Protein amino acid } \\
\text { dephosphorylation }\end{array}$ & GO: 0016791 & Phosphatase activity & -4 & +4 \\
\hline $1 \mathrm{hbi}$ & 31.1 & $\begin{array}{l}\text { RING-type ubiquitin ligase } \\
\text { (C3H4 RING zinc finger } \\
\text { family protein) }\end{array}$ & GO: 0006511 & $\begin{array}{l}\text { Ubiquitin-dependent } \\
\text { protein catabolic } \\
\text { process }\end{array}$ & GO: 0005515 & Protein binding & -2 & +3 \\
\hline 13 dpi & 317.1 & $\begin{array}{l}\text { Putative ubiquitin carboxyl- } \\
\text { terminal hydrolase }\end{array}$ & GO: 0006511 & $\begin{array}{l}\text { Ubiquitin-dependent } \\
\text { protein catabolic } \\
\text { process }\end{array}$ & GO: 0004221 & $\begin{array}{l}\text { Ubiquitin thiolesterase } \\
\text { activity }\end{array}$ & $-1 ;+1$ & +2 \\
\hline 13 dpi & 232.2 & Serine carboxypeptidase & GO: 0006508 & Proteolysis & GO: 0004185 & $\begin{array}{l}\text { Serine-type } \\
\text { carboxypeptidase activity }\end{array}$ & +2 & +3 \\
\hline $1 \mathrm{hbi}$ & 47.1 & Glycolipid transfer protein & GO: 0046836 & Glycolipid transport & GO: 0017089 & $\begin{array}{l}\text { Glycolipid transporter } \\
\text { activity }\end{array}$ & -1 & +3 \\
\hline 13 dpi & 283.1 & Glycolipid transfer protein & GO: 0046836 & Glycolipid transport & GO: 0017089 & $\begin{array}{l}\text { Glycolipid transporter } \\
\text { activity }\end{array}$ & -1 & +3 \\
\hline $1 \mathrm{hbi}$ & 33.2 & $\begin{array}{l}\text { Dopamine beta- } \\
\text { monooxygenase }\end{array}$ & GO: 0042420 & $\begin{array}{l}\text { Dopamine catabolic } \\
\text { process }\end{array}$ & GO: 0004500 & $\begin{array}{l}\text { Dopamine monooxygenase } \\
\text { activity }\end{array}$ & +1 & +4 \\
\hline 13 dpi & 294.2 & Cellulose synthase & GO: 0030244 & $\begin{array}{l}\text { Cellulose biosynthetic } \\
\text { process }\end{array}$ & GO: 0016760 & Cellulose synthase activity & -2 & -2 \\
\hline 13 dpi & 190.2 & $\begin{array}{l}\text { CCR4-associated factor 1- } \\
\text { related protein }\end{array}$ & GO: 0009451 & RNA modification & GO: 0004540 & Ribonuclease activity & $-1 ;+1$ & +2 \\
\hline $1 \mathrm{hbi}$ & 44.1 & Hypothetical protein & $\ldots$ & $\ldots$ & $\ldots$ & $\ldots$ & -4 & -4 \\
\hline
\end{tabular}

${ }^{a}$ Genes identified by cDNA-amplified fragment length polymorphism (AFLP) were grouped into gene ontology (GO) categories according to biological process and molecular function.

${ }^{\mathrm{b}}$ Estimate of the extent of differential transcription of the selected genes on a semiquantitative scale, as measured in confirmatory real-time RT-PCR assays performed on material collected at both times; + means upregulation in $\mathrm{S}^{-}$compared with $\mathrm{S}^{+}$crown tissue and - means downregulation in $\mathrm{S}^{-}$compared with $\mathrm{S}^{+}$ crown tissue. The regulation levels defined for $\mathrm{S}^{-}$tissue are \pm 1 : less than twofold up- or downregulation; \pm 2 : two- to fivefold up- or downregulation; \pm 3 : five- to tenfold up- or downregulation; \pm 4 : more than tenfold up- or downregulation. When only one level appears, it is the mean of the results of the two biological replicates. When two levels appear, the two replicates showed different regulation trends and the values obtained for both replicates are given separately.

${ }^{\mathrm{c}}$ Time of collection: $1 \mathrm{~h}$ before pathogen inoculation $(1 \mathrm{hbi})$ or 13 days postinoculation $(13 \mathrm{dpi})$.

${ }^{\mathrm{d}}$ Transcript derived fragment. 
tion on this enzyme and its substrates in the crowns. By correlating the levels of various catecholamines in crowns with different levels of susceptibility, it might be possible to gain insight about their respective roles. Furthermore, quantification of the potential antifungal activities of catecholamines could indicate whether they are active by themselves in defense mechanisms or whether they are precursors of other active compounds.

Finally, evaluating the expression levels of these genes in other conditions that promote variation in susceptibility level is needed to determine whether the genes are involved in quantitative regulation of banana defense responses rather than in pathways that are triggered by a change in the source/sink ratio independent of the plant defense response. Furthermore, because plant defense responses invariably are multicomponent processes, it is not easy to determine which components are both necessary and sufficient to confer protection.

\section{MATERIALS AND METHODS}

\section{Fruit sampling.}

Banana fruit were harvested from plants (M. acuminata, AAA, cv. Grande-Naine) grown on the Dia-Dia commercial plantation
(PHP) in Njombé, Cameroon (altitude: $80 \mathrm{~m}$; annual mean temperature: $26.5^{\circ} \mathrm{C}$; annual mean rainfall: $3,500 \mathrm{~mm}$ ). The date of flowering was indicated by tying a colored belt to each bunch (banana inflorescence) at the horizontal finger stage in order to predict the time of harvest. Bunches were also covered with a plastic sleeve at this stage. Bunches were harvested at a constant physiological age (Jullien et al. 2008) (i.e., when the mean daily temperature sum accumulated by the fruit at the $14^{\circ} \mathrm{C}$ threshold between flowering and harvest reached 900 degree days). Temperatures were recorded at a weather station on the plantation. The daily average temperature was estimated from measurements of maximum and minimum temperature. To obtain banana fruit with different levels of susceptibility to crown rot, fruit were harvested from plants characterized by different source/sink ratios (Lassois et al. 2010a) established at the flowering stage, leaves being viewed as sources and fruit as sinks.

Plants showing a low susceptibility to crown rot disease were called $\mathrm{S}^{-}$. These plants were obtained through severe trimming of bunches at flowering stage. These plants had 12 leaves and two hands (a hand is a group of banana fruit) left on the bunch. Two plants of this treatment were used $\left(\mathrm{S}^{-}\right.$plant 1 and $\mathrm{S}^{-}$plant 2) and constitute the two biological replicates.

\section{Banana plant with 12Leaves/2Hands S- Plants (Low fruit susceptibility to C. musae)}

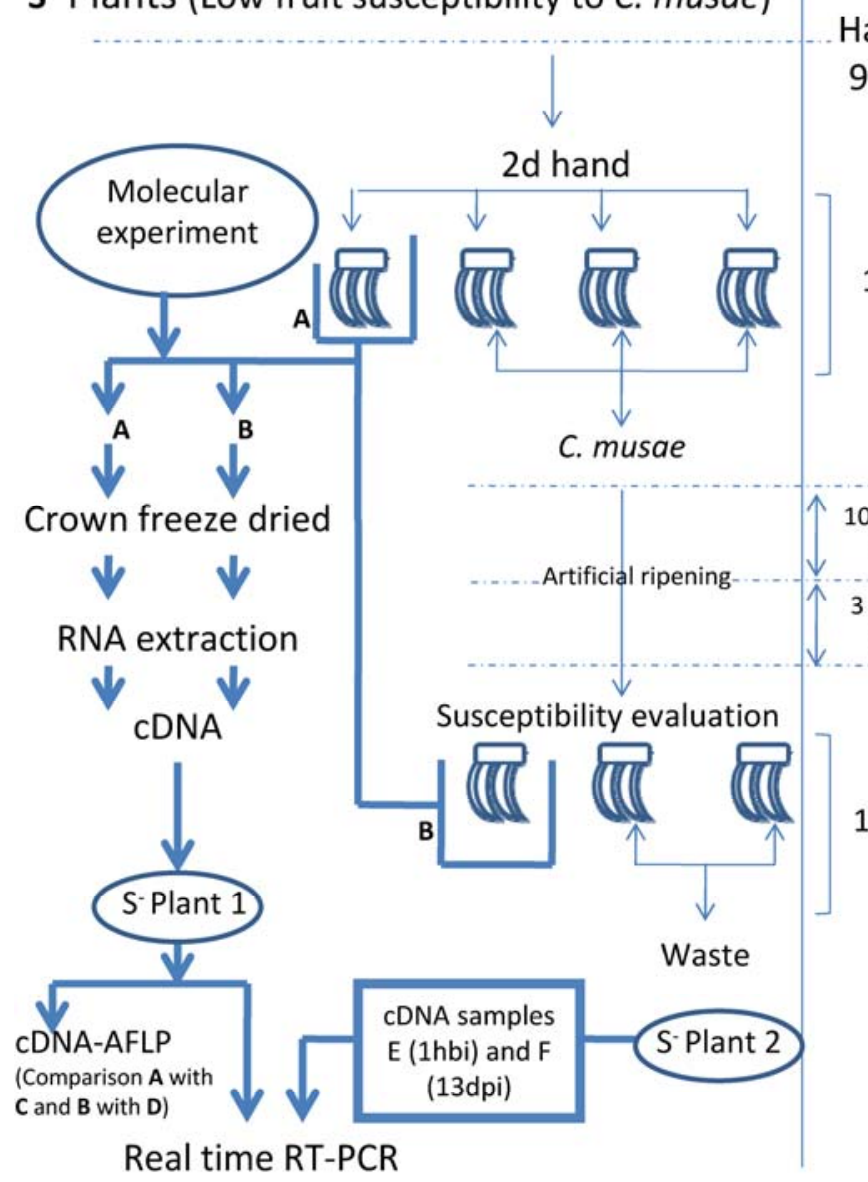

Banana plant with 12Leaves/8Hands $\mathbf{S}^{+}$Plants (high fruit susceptibility to $C$. musae)

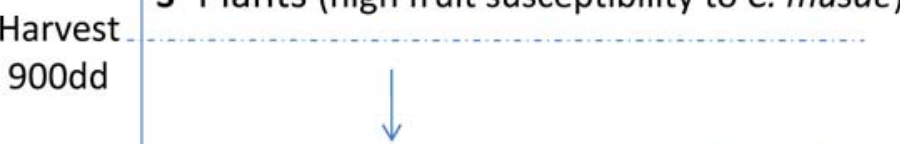

$1 \mathrm{hbi}$
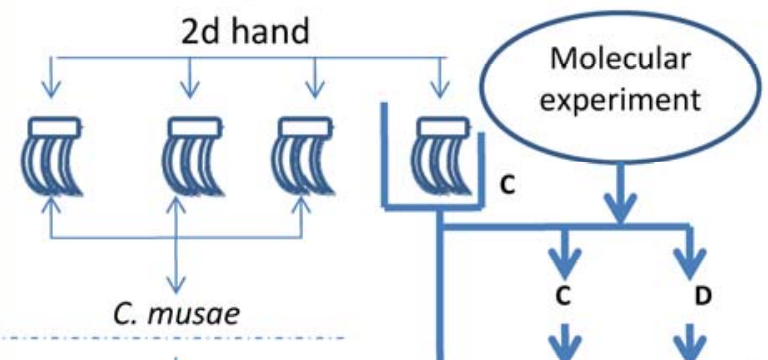

Crown freeze dried

RNA extraction

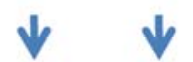

Susceptibility evaluation

$13 \mathrm{dpi}$

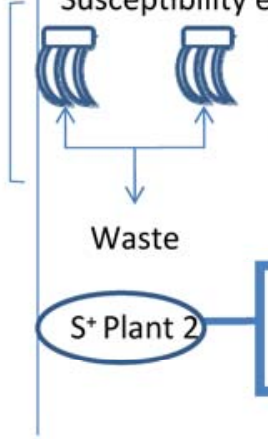

cDNA

Fig. 3. Experimental procedure. Because banana fruit from plants with 12 leaves and two hands were expected to be less susceptible than banana fruit from plants with 12 leaves and eight hands (Lassois et al. 2010a), two plants with each configuration were used as source material: low-susceptibility $\left(\mathrm{S}^{-}\right)$plant 1and 2 and high-susceptibility $\left(\mathrm{S}^{+}\right)$plant 1 and 2. Only the second hand of each bunch was collected and each one was divided into four clusters of four fingers without defects. $\mathrm{S}^{-}$plant 1 and $\mathrm{S}^{+}$plant 1 were used as sources of material for cDNA-amplified fragment length polymorphism analysis and for one replicate of the real time reverse-transcription polymerase chain reaction (RT-PCR). Samples A and B were collected from S- plant $11 \mathrm{~h}$ before inoculation (1 hbi) and 13 days postinoculation ( $13 \mathrm{dpi}$ ), respectively. Likewise, samples $\mathrm{C}$ and $\mathrm{D}$ were collected from the $\mathrm{S}^{+}$plant $11 \mathrm{hbi}$ and 13 dpi, respectively. Following the same procedure, samples $\mathrm{E}(1 \mathrm{hbi})$ and $\mathrm{F}(13 \mathrm{dpi})$ were collected from $\mathrm{S}^{-}$plant 2 and samples $\mathrm{G}(1 \mathrm{hbi})$ and $\mathrm{H}(13 \mathrm{dpi})$ from S $\mathrm{S}^{+}$plant 2 . These samples provided the second biological replicate used for result confirmation by real time RT-PCR. Furthermore, three clusters of each selected hand were used to evaluate fruit susceptibility to Colletotrichum musae at 13 dpi to confirm the expected $\mathrm{S}^{+}$or $\mathrm{S}^{-}$status of each source.

Vol. 24, No. 1, 2011 / 149 
Plants showing a high susceptibility to crown rot disease were called $\mathrm{S}^{+}$. These plants were reference plants without severe trimming of bunch. At flowering, bunches were not trimmed; therefore, these plants had 12 leaves and eight hands left on the bunch. Two plants of this treatment were used $\left(\mathrm{S}^{+}\right.$plant 1 and $\mathrm{S}^{+}$ plant 2) and constitute the two biological replicates.

The experimental sampling design for fruit susceptibility evaluation and molecular analysis is outlined in Figure 3, while Table 4 identifies the samples, with their respective sources and processing modalities. Only the second hand of each bunch was collected and each one was divided into four clusters of four fingers (fruit) without defects. Each sample group consisted of clusters from the same hand, so as to avoid variability due to susceptibility variations among different hands (Lassois et al. 2010a). At harvest for each bunch, one cluster was used for sampling crown at $1 \mathrm{hbi}$ of $C$. musae (1 hbi = clusters A, C, E, and G according to the treatment and the biological replicate; not ethrel treated) and three clusters were inoculated with $C$. musae (Fig. 3). These three clusters were used for fruit susceptibility evaluation in order to confirm the expected $\mathrm{S}^{+}$or $\mathrm{S}^{-}$status of each treatment. One of these three was collected for crown sampling at 13 dpi when symptoms are developed (13 dpi = clusters B, D, F, and $\mathrm{H}$ according to the treatment and the biological replicate; ethrel treated). The crowns collected at each period ( $1 \mathrm{hbi}$ and $13 \mathrm{dpi}$ ) for molecular analyses were immediately frozen in liquid nitrogen, freeze dried at $-80^{\circ} \mathrm{C}$ for $24 \mathrm{~h}$ (Telstar, Cryodos, Barcelona, Spain), and stored at room temperature before RNA extraction (Lassois et al. 2009) and molecular analysis.

\section{Inoculation of fruit for the evaluation of susceptibility to crown rot.}

The C. musae strain was isolated in Njombé, Cameroon. It was sensitive to thiabendazole and was stored at $-20^{\circ} \mathrm{C}$ in a glycerol solution $(30 \%)$. Before use, it was grown at $25^{\circ} \mathrm{C}$ in Mathur medium $\left(\mathrm{MgSO}_{4} \cdot 7 \mathrm{H}_{2} \mathrm{O}\right.$ at $2.5 \mathrm{~g} /$ liter, $\mathrm{KH}_{2} \mathrm{PO}_{4}$ at 2.7 $\mathrm{g} /$ liter, peptone at $1 \mathrm{~g} / \mathrm{liter}$, yeast extract at $1 \mathrm{~g} / \mathrm{liter}$, saccharose at $10 \mathrm{~g} /$ liter, and agar at $15 \mathrm{~g} /$ liter) for 10 days. Conidia were removed by flooding the plates with sterile distilled water and filtration through a $45-\mu \mathrm{m}$ sieve. The concentrations of the conidial suspension was determined with a Mallassez cell.

Smoothly and similarly cut crowns were obtained with a sharp knife, leaving as much crown tissue as possible. The latex from the crown tissue was eliminated with absorbent paper and the crowns were surface sterilized by immersion in $50 \%$ ethanol. C. musae conidial suspension $(50 \mu \mathrm{l})$ containing $10^{4}$ conidia/ml was applied to the center of the freshly exposed crown tissue and covered with a small paper filter. Two hours after application of the conidial suspension, the clusters were packed in punched polyfilms normally used in the industry, placed in commercial boxes, and stored at $13^{\circ} \mathrm{C}$ for 10 days to simulate shipment. Artificial ripening was then initiated by dipping the banana fruit for $5 \mathrm{~s}$ in an ethrel solution (480 $\mathrm{g} /$ liter), after which the clusters remained at $20^{\circ} \mathrm{C}$ for another
3 days before crown rot assessment. The internal progression of the rot was determined by cutting the cluster crown longitudinally in two and measuring the surface of rot spread into the crown, from the original inoculation point. This INS, calculated by assuming a rectangular shape, was expressed in square millimeters (Fig. 4). The average value of the three replicates was taken as a measure of fruit susceptibility to crown rot.

\section{RNA isolation and reverse transcription.}

Total RNA was extracted from the eight lyophilized crown samples (Table 4, A-H) by the hot borate method (Wan and Wilkins 1994) modified by Mbéguié-A-Mbéguié and associates (2008) and as described by Lassois and associates (2009). RNA extracts were treated for $30 \mathrm{~min}$ at $37^{\circ} \mathrm{C}$ with 20 units of RNase-free DNase (Roche, Basel, Switzerland) in the presence of 40 units of RNase inhibitor (Roche Diagnostics, Mannheim, Germany). The RNA yield was determined by measuring the absorbance at $260 \mathrm{~nm}$ with an ND-1000 nanodrop spectrophotometer (Isogen Life Sciences, Maarssen, The Netherlands), and sample purity was estimated by the absorbance at 260 $\mathrm{nm} /$ absorbance at $280 \mathrm{~nm}$ ratio. RNA integrity was evaluated by the sharpness of the bands corresponding to $28 \mathrm{~S}$ and $18 \mathrm{~S}$ ribosomal RNA visualized by ethidium bromide staining on a $1 \%$ agarose gel. Double-stranded cDNA was synthesized from total RNA according to the instructions for use of the Superscript Double-Stranded cDNA Synthesis Kit (Invitrogen, Carlsbad, CA, U.S.A.).

\section{Identification of genes differently expressed between crowns of banana with high and low susceptibility to crown rot disease by cDNA-AFLP.}

The cDNA pools derived from $\mathrm{S}^{+}$plant 1 and $\mathrm{S}^{-}$plant 1 (samples A to D) (Table 4; Fig. 3) were subjected to cDNA-AFLP.

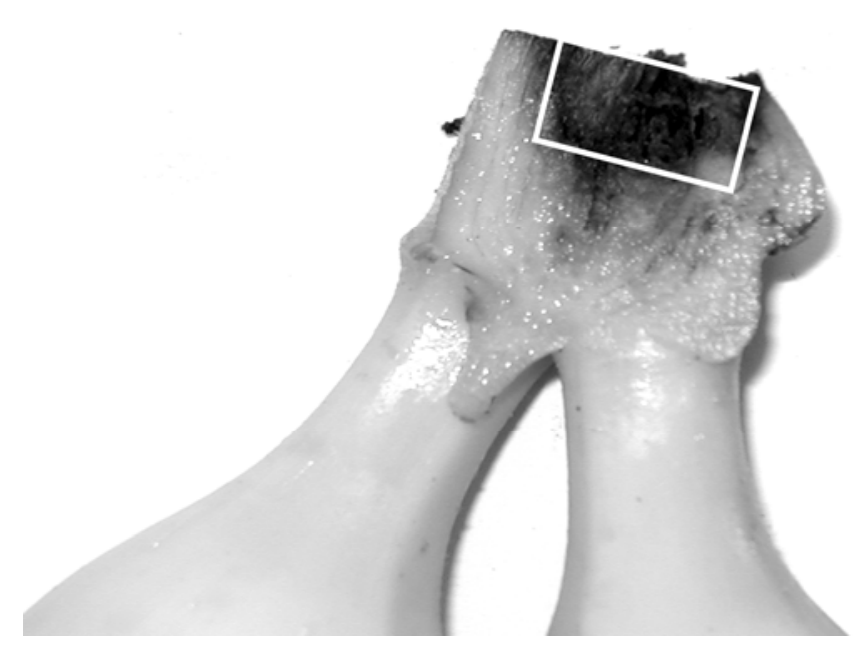

Fig. 4. Evaluation of crown susceptibility. Internal necrotic surface was calculated assuming a rectangular shape and is expressed in square millimeters.

Table 4. Presentation of the various collected samples used for molecular analysis in order to identify genes differently expressed in banana crowns showing high and low susceptibility to crown rot disease ${ }^{\mathrm{a}}$

\begin{tabular}{|c|c|c|c|c|c|c|c|c|}
\hline \multirow{2}{*}{$\frac{\text { Parameters }}{\text { Susceptibility level }}$} & \multicolumn{4}{|c|}{ Biological replicate 1} & \multicolumn{4}{|c|}{ Biological replicate 2} \\
\hline & \multirow{2}{*}{\multicolumn{2}{|c|}{$\begin{array}{c}\mathrm{S}^{-} \text {plant } 1 \\
12 \text { leaves/two hands }\end{array}$}} & \multirow{2}{*}{\multicolumn{2}{|c|}{$\begin{array}{c}S^{+} \text {plant } 1 \\
12 \text { leaves/eight hands }\end{array}$}} & \multirow{2}{*}{\multicolumn{2}{|c|}{$\begin{array}{c}\mathrm{S}^{-} \text {plant } 2 \\
12 \text { leaves/two hands }\end{array}$}} & \multicolumn{2}{|c|}{$\mathrm{S}^{+}$plant 2} \\
\hline Source/sink ratio & & & & & & & 12 leas & thands \\
\hline Collecting time & $1 \mathrm{hbi}$ & $13 \mathrm{dpi}$ & $1 \mathrm{hbi}$ & $13 \mathrm{dpi}$ & $1 \mathrm{hbi}$ & 13 dpi & $1 \mathrm{hbi}$ & $13 \mathrm{dpi}$ \\
\hline Ethrel treatment & No & Yes & No & Yes & No & Yes & No & Yes \\
\hline Crown identification & A & B & $\mathrm{C}$ & $\mathrm{D}$ & $\mathrm{E}$ & $\mathrm{F}$ & $\mathrm{G}$ & $\mathrm{H}$ \\
\hline
\end{tabular}

${ }^{a} \mathrm{~S}^{-}$stands for low susceptibility and $\mathrm{S}^{+}$for high susceptibility. Crowns were collected $1 \mathrm{~h}$ before inoculation (1 hbi) or 13 days postinoculation (13 dpi) of clusters from the second hand. cDNA pools obtained after RNA extraction and reverse transcription are labeled A-H. In the cDNA-amplified fragment length polymorphism (AFLP) analysis, sample A was compared with C (two susceptibility levels, 1 hbi) and sample B with D (two susceptibility levels, 13 $\mathrm{dpi}$ ). In the real-time reverse-transcription polymerase chain reaction assays, $\mathrm{A}$ and $\mathrm{E}$ yielded biological replicates, as did $\mathrm{B}$ and $\mathrm{F}$, $\mathrm{C}$ and $\mathrm{G}$, and $\mathrm{D}$ and $\mathrm{H}$. 
For each collection time ( 1 hbi or $13 \mathrm{dpi}$ ), the $\mathrm{S}^{+}$and $\mathrm{S}^{-}$samples were compared. Thus, A was compared with $\mathrm{C}(1 \mathrm{hbi})$ and B with D (13 dpi).

Double-stranded cDNA was digested with EcoRI and MseI, ligated with $E c o$ RI and $M s e I$ adapters, and preamplified with Eco (5'-GACTGCGTACCAATTC-3') and $M s e$ (5'-GATGAGT CCTGAGTAA-3') primers according to the instructions of the AFLP Analysis System kit for microorganisms (Invitrogen). After 20-fold dilution of the PCR fragments, specific amplifications were carried out with eight primer combinations of an Eco primer and an Mse primer containing two additional bases at their $3^{\prime}$ ends. The Eco primers were labeled with $\gamma^{33} \mathrm{P}$ dATP. Amplification products were separated by electrophoresis at $50 \mathrm{~W}$ on a vertical denaturing polyacrylamide gel $(6 \%)$ containing $7 \mathrm{M}$ urea. Gels were dried on Whatman paper before autoradiography.

The film and gel were aligned and the fragments of interest were excised from the gel with a sterile razor blade and immersed overnight in $100 \mu \mathrm{l}$ of distilled water. Of this solution, 5 $\mu \mathrm{l}$ was used in a standard PCR with the same EcoRI and MseI primers as used in the preamplification step described above. After separation of the amplified products in a $1.2 \%$ agarose gel, the bands were excised and purified as recommended with the QiaEx II gel extraction kit (Qiagen, Venlo, Pays-Bas).

The DNA fragments were ligated to the pJET1.2 vector according to the instructions of the Clonejet PCR cloning kit (Fermentas, Vilnius, Lithuania) and cloned into Escherichia coli (Ultracomp INV $\alpha F^{\prime}$; Invitrogen). After transformation, bacterial cells were spread onto NZY (NZ-amineA, yeast extract) medium (2.1\% NZY [Fisher Scientific, Tournai, Belgium], $1.5 \%$ agar, $\mathrm{pH} 7.0$ ) containing ampicillin at $100 \mu \mathrm{g} / \mathrm{ml}$. After incubation for at least $30 \mathrm{~h}$ at $37^{\circ} \mathrm{C}$, five colonies per fragment were chosen and cultured overnight at $37^{\circ} \mathrm{C}$ in liquid NZY medium containing ampicillin. Plasmids containing the PCR product were extracted with the GeneJet Plasmid miniprep kit (Fermentas), according to the instructions. The presence of inserts in plasmids was checked by standard PCR amplification with pJET forward and reverse primers (Fermentas).

Three colonies were selected for sequence analysis for each TDF. Sequencing was carried out with an automated sequencer (AbiPrism3730XL; Applied Biosystems, Foster City, CA, U.S.A.) by Macrogen Inc. (Seoul, South Korea) with the pJET forward primer of the Clonjet PCR Cloning Kit (Fermentas). Sequence alignments were performed and the sequence of each fragment corrected by means of the Bioedit sequence alignment editor software developed by the Microbiology Department of North Carolina University (Raleigh, U.S.A.). Sequence homology was determined with the Basic Local Alignment and Search Tool (BlastX program) from the National Center for Biotechnology Information. The identified putative protein sequences were used in queries against the UniProt database. Homologies with $E$ value scores below $10^{-8}$ were considered significant.

\section{cDNA-AFLP fragment validation by real-time RT-PCR.}

The results obtained by cDNA-AFLP were confirmed for selected TDF by real-time RT-PCR (with two independent biological replicates) (Table 4). In these confirmation tests, expression-level differences between identically processed $\mathrm{S}^{-}$ and $\mathrm{S}^{+}$samples were determined for both collection times (1 hbi and $13 \mathrm{dpi}$ ) and expressed as described in the legend of Table 3. Hence, samples A and E yielded biological replicate, as did $\mathrm{B}$ and F, C and $\mathrm{G}$, and $\mathrm{D}$ and $\mathrm{H}$. Template-free controls (water instead of cDNA) were included. Three technical replicates were done for each biological replicate.

For each TDF, the forward and reverse primers were designed on the basis of the isolated sequence, with the online
Primer3 software under default settings. Newly designed primers were ordered from and synthesized at Eurogentec (Seraing, Belgium).

Real-time RT-PCR was carried out with StepOne ${ }^{+}$RealTime PCR systems (Applied Biosystems,). Each PCR amplification was performed in $20 \mu \mathrm{l}$ of reaction mixture consisting of $10 \mu \mathrm{l}$ of Maxima SYBR Green qPCR Master Mix 2X (Fermentas), $2 \mu \mathrm{l}$ each of the forward and reverse primers (10 $\mu \mathrm{M}), 1 \mu \mathrm{l}$ of cDNA template $(1 \mathrm{ng} / \mu \mathrm{l})$, and $5 \mu \mathrm{l}$ of PCR-grade water. The cycling conditions consisted of preincubation for 10 min at $95^{\circ} \mathrm{C}$ followed by 40 cycles, each consisting of $30 \mathrm{~s}$ of denaturing at $95^{\circ} \mathrm{C}, 40 \mathrm{~s}$ of annealing at $52^{\circ} \mathrm{C}$, and $45 \mathrm{~s}$ of elongation at $72^{\circ} \mathrm{C}$, the last cycle ending with a final 10 -min extension at $72^{\circ} \mathrm{C}$. Melting curve analysis $\left(60\right.$ to $\left.95^{\circ} \mathrm{C}\right)$ was performed to validate the gene specificity of the primers. Only genes with clear melting curves were taken for further data analysis. Samples showing irregular melting peaks were excluded from the quantification procedure. Differences in expression were calculated according to the $\Delta \Delta$ method (Pfaffl 2001), elongation factor $1-\alpha$ being used as an internal control for normalization (Czechowski et al. 2005; Eungwanichayapant and Popluechai 2009). RT-PCR analyses and subsequent calculations were performed with the StepOne software (Applied Biosystems).

Genes identified by cDNA-AFLP analysis and confirmed in both real time RT-PCR biological replicates to be differently expressed to a significant degree in $\mathrm{S}^{+}$and $\mathrm{S}^{-}$banana crown tissues were grouped into gene ontology (GO) categories according to biological process and molecular function. To obtain the GO annotations of our proteins, we downloaded those of Arabidopsis proteins from The Arabidopsis Information Resource website as reference annotations. The Arabidopsis protein GO annotations were extended to the proteins found in this study.

\section{ACKNOWLEDGMENTS}

We thank O. Nguidjo and R. Dongmo, working in the African Center for Research on Bananas and Plantains (Cameroon), where samples were collected and lyophilized, for their precious technical assistance; and the Plantations du Haut Penja (PHP, Cameroon) for kind disposal of experimental plots for this study.

\section{LITERATURE CITED}

Agrawal, G. K., Rakwal, R., and Iwahashi, H. 2002. Isolation of novel rice (Oryza sativa L.) multiple stress responsive MAP kinase gene, OsMSRMK2, whose mRNA accumulates rapidly in response to environmental cues. Biochem. Biophys. Res. Commun. 294:1009-1016.

Agrawal, G. K., Iwahashi, H., and Rakwal, R. 2003. Rice MAPKs. Biochem. Biophys. Res. Commun. 302:171-180.

Avrova, A. O., Stewart, H. E., De Jong, W., Heilbronn, J., Lyon, G. D., and Birch, P. R. J. 1999. A cysteine protease gene is expressed early in resistant potato interactions with Phytophthora infestans. Mol. Plant-Microbe Interact. 12:1114-1119.

Bachem, C. 1996. Visualization of differential gene expression using a novel method of RNA fingerprinting based on AFLP: Analysis of gene expression during potato tuber development. Plant J. 9:745-753.

Bachem, C., Oomen, R., and Visser, R. 1998. Transcript imaging with cDNA-AFLP: A step by step protocol. Plant Mol. Biol. Rep. 16:157173.

Botton, A., Ferrigo, D., Scopel, C., Causin, R., Bonghi, C., and Ramina, A. 2008. A cDNA-AFLP approach to study ochratoxin A production in Aspergillus carbonarius. Int. J. Food Microbiol. 127:105-115.

Boyes, D. C., Nam, J., and Dangl, J. L. 1998. The Arabidopsis thaliana RPM1 disease resistance gene product is a peripheral plasma membrane protein that is degraded coincident with the hypersensitive response. Proc. Natl. Acad. Sci. U.S.A. 95:15849-15854.

Breyne, P., Dreesen, R., Cannoot, B., Rombaut, D., Vandepoele, K., Rombauts, S., Vanderhaeghen, R., Inze, D., and Zabeau, M. 2003. Quantitative cDNA-AFLP analysis for genome-wide expression studies. Mol. Genet. Genomics 269:173-179. 
Brown, R. E., and Mattjus, P. 2007. Glycolipid transfer proteins. Biochim. Biophys. Acta 1771:746-776.

Campalans, A., Pagès, M., and Messeguer, R. 2001. Identification of differentially expressed genes by the cDNA-AFLP technique during dehydration of almond. Tree Physiol. 21:633-643.

Cano-Delgado, A., Penfield, S., Smith, C., Catley, M., and Bevan, M. 2003. Reduced cellulose synthesis invokes lignification and defense responses in Arabidopsis thaliana. Plant J. 34:351-362.

Chen, G. P., Ma, W. S., Huang, Z. J., Xu, T., Xue, Y. B., and Shen, Y. Z. 2003. Isolation and characterization of TaGSK1 involved in wheat salt tolerance. Plant Sci. 165:1369-1375.

Chen, W. H., Tseng, I. C., Tsai, W. C., Chiang, M. S., Chen, Y. H., and Chen, H. H. 2006. AFLP fingerprinting and conversion to sequence-tag site markers for the identification of Oncidium cultivars. J. Hortic. Sci. Biotechnol. 81:791-796

Czechowski, T., Stitt, M., Altmann, T., Udvardi, M. K., and Scheible, W. 2005. Genome-wide identification and testing of superior reference genes for transcript normalization in Arabidopsis. Plant Physiol. 139:517.

Dal Degan, F., Rocher, A., Cameron-Mills, V., and von Wettstein, D. 1994. The expression of serine carboxypeptidases during maturation and germination of the barley grain. Proc. Natl. Acad. Sci. U.S.A. 91:82098213.

de Lapeyre de Bellaire, L., Chillet, M., and Chilin-Charles, Y. 2008. Determination of banana fruit susceptibility to post-harvest diseases: Wound anthracnose, quiescent anthracnose and crown-rot. Fruits 63:183-186.

Devoto, A., Muskett, P. R., and Shirasu, K. 2003. Role of ubiquitination in the regulation of plant defence against pathogens. Curr. Opin. Plant Biol. 6:307-311

Dilger, M., Felsenstein, F. G., and Schwarz, G. 2003. Identification and quantitative expression analysis of genes that are differentially expressed during conidial germination in Pyrenophora teres. Mol. Genet. Genomics 270:147-155.

Ditt, R. F., Nester, E. W., and Comaij, L. 2001. Plant gene expression response to Agrobacterium tumefaciens. Proc. Natl. Acad. Sci. U.S.A. 98:10954-10959.

Dong, W., Latijnhouwers, M., Jiang, R. H. Y., Meijer, H. J. G., and Govers, F. 2004. Downstream targets of the Phytophthora infestans $\mathrm{G} \alpha$ subunit PiGPA1 revealed by cDNA-AFLP. Mol. Plant Pathol. 5:483-494.

Edelmann, M. J., and Kessler, B. M. 2008. Ubiquitin and ubiquitin-like specific proteases targeted by infectious pathogens: Emerging patterns and molecular principles. Biochim. Biophys. Acta (BBA) Mol. Basis Dis. 1782:809-816.

Ellis, C., Turner, J. G., and Devoto, A. 2002. Protein complexes mediate signalling in plant responses to hormones, light, sucrose and pathogens. Plant Mol. Biol. 50:971-980.

Eungwanichayapant P. D., and Popluechai, S. 2009. Accumulation of catechins in tea in relation to accumulation of mRNA from genes involved in catechin biosynthesis. Plant Physiol. Biochem. 47:94-97.

Finlay, A. R., and Brown, A. E. 1993. The relative importance of Colletotrichum musae as a crown-rot pathogen on Windward Island bananas. Plant Pathol. 42:67-74.

Fukuda, T., Kido, A., Kajino, K., Tsutsumi, M., Miyauchi, Y., Tsujiuchi, T., Konishi, Y., and Hino, O. 1999. Cloning of differentially expressed genes in highly and low metastatic rat osteosarcomas by a modified cDNA-AFLP method. Biochem. Biophys. Res. Commun. 261:35-40.

Granat, S. J., Wilson, K. A., and Tan-Wilson, A. L. 2003. New serine carboxypeptidases in mung bean seedling cotyledons. J. Exp. Bot. 160:1263-1266

Guo, J., Jiang, R. H. Y., Kamphuis, L. G., and Goversj, F. 2006. A cDNAAFLP based strategy to identify transcripts associated with avirulence in Phytophthora infestans. Fungal Genet. Biol. 43:111-123.

Hsu, T.-W., Tsai, W.-C., Wang, D.-P., Lin, S., Hsiao, Y.-Y., Chen, W.-H., and Chenj, H.-H. 2008. Differential gene expression analysis by cDNAAFLP between flower buds of Phalaenopsis hsiang fei $\mathrm{cv}$. H. F. and its somaclonal variant. Plant Sci. 175:415-422.

Jullien, A., Chillet, M., and Malezieux, E. 2008. Pre-harvest growth and development, measured as accumulated degree days, determine the post-harvest green life of banana fruit. J. Hortic. Sci. Biotechnol. 83:506-512.

Krauss, U., and Johanson, A. 2000. Recent advances in the control of crown rot of banana in the Windward Islands. Crop Prot. 19:151-160.

Kruger, J., Thomas, C. M., Golstein, C., Dixon, M. S., Smoker, M., Tang, S., Mulder, L., and Jones, J. D. G. 2002. A tomato cysteine protease required for Cf-2-dependent disease resistance and suppression of autonecrosis. Science 296:744-747.

Kuhn, E. 2001. From library screening to microarray technology: Strategies to determine gene expression profiles and to identify differentially regulated genes in plants. Ann. Bot. 87:139-155.

Kulma, A., and Szopa, J. 2007. Catecholamines are active compounds in plants. Plant Sci. 172:433-440.

Lassois, L., de Lapeyre de Bellaire, L., and Jijakli, M. H. 2008. Biological control of crown rot of bananas with Pichia anomala strain K and Candida oleophila strain O. Biol. Control 45:410-418.

Lassois, L., de Lapeyre de Bellaire, L., and Jijakli, M. H. 2009. Combining an original method for preserving RNA expression in situ with an effective RNA extraction method makes it possible to study gene expression in any banana fruit tissue. Fruits $64: 127-137$.

Lassois, L., Bastiaanse, H., Chillet, M., Jullien, A., Jijakli, H., and de Lapeyre de Bellaire, L. 2010a. Hand position on the bunch and sourcesink ratio influence the level of banana fruit susceptibility to crown rot disease. Ann. Appl. Biol. 156:221-229.

Lassois, L., Jijakli, M. H., Chillet, M., and de Lapeyre de Bellaire, L. 2010b. Crown rot of bananas: Pre-harvest factors involved in post-harvest disease development and integrated control methods. Plant Dis. 94:648-658.

Lecourieux-Quaked, F., Pugin, A., and Lebrun-Garcia, A. 2000. Phosphoproteins involved in the signal transduction of cryptogein, an elicitor of defense reactions in tobacco. Mol. Plant-Microbe Interact 13:821-829.

Lee, S., Kim, S.-Y., Chung, E., Joung, Y.-H., Pai, H.-S., Hur, C.-G., and Choi, D. 2004. EST and microarray analyses of pathogen-responsive genes in hot pepper (Capsicum аппиum L.) non-host resistance against soybean pustule pathogen (Xanthomonas axonopodis pv. glycines). Funct. Integr. Genomics 4:196-205.

Liang, W., Li, C., Liu, F., Jiang, H., Li, S., Sun, J., Wu, X., and Li, C. 2009. The Arabidopsis homologs of CCR4-associated factor 1 show mRNA deadenylation activity and play a role in plant defence responses. Cell Res. 19:307-316.

Lucas, J. A. 1998. Plant pathology and plant pathogens. Blackwell Science, Oxford, U.K. and Malden, MA, U.S.A.

Lukezic, F. L., Kaiser, W. J., and Martinez, M. M. 1967. The incidence of crown rot of boxed bananas in relation to microbial populations of the crown tissues. Can. J. Bot. 45:413-421

Mace, M. E. 1963. Histochemical localization of phenols in healthy and diseased banana roots. Physiol. Plant. 16:915-925.

Massart, S., and Jijakli, H. 2006. Identification of differentially expressed genes by cDNA-amplified fragment length polymorphism in the biocontrol agent Pichia anomala (strain Kh5). Phytopathology 96:80-86.

Mbéguié-A-Mbéguié, D., Fils-Lycaon, B., Chillet, M., Hubert, O., Galas, C., and Gomez, R. 2008. Extraction and purification of total RNA from banana tissues (small scale). Fruits 63:255-261.

Moura, D. S., Bergey, D. R., and Ryan, C. A. 2001. Characterization and localization of a wound-inducible type I serine-carboxypeptidase from leaves of tomato plants (Lycopersicon esculentum Mill.). Planta $212: 222-230$

Muirhead, I. F., and Deverall, B. J. 1984. Evaluation of 3,4-dihydrobenzaldehyde, dopamine and its oxidation products as inhibitors of Colletotrichum musae (Berk. et Curt.) Arx in green banana fruits. Aust. J. Bot. 32:575-582.

Nurnberger, T., Brunner, F., Kemmerling, B., and Piater, L. 2004. Innate immunity in plants and animals: Striking similarities and obvious differences. Immunol. Rev. 198:249-266.

Pautot, V., Holzer, F. M., Reisch, B., and Walling, L. L. 1993. Leucine aminopeptidase: An inducible component of the defense response in Lycopersicon esculentum (tomato). Proc. Natl. Acad. Sci. U.S.A. 90:9906-9910.

Pfaffl, M. W. 2001. A new mathematical model for relative quantification in real-time RT-PCR. Nucleic Acids Res. 29:2002-2007.

Rakwal, R., Shii, K., Agrawal, G. K., and Yonekura, M. 2001. Protein phosphatase inhibitors activate defense responses in rice (Oryza sativa) leaves. Physiol. Plant. 111:151-157.

Ramonell, K., Berrocal-Lobo, M., Koh, S., Wan, J., Edwards, H., Stacey, G., and Somerville, S. 2005. Loss-of-function mutations in chitin responsive genes show increased susceptibility to the powdery mildew pathogen Erysiphe cichoracearum. Plant Physiol. 138:1027-1036.

Reijans M., Lascaris, R., Groeneger, A. O., Wittenberg, A., Wesselink, E., van Oeveren, J., de Wit, E., Boorsma, A., Voetdijk, B., and van der Spek, H. 2003. Quantitative comparison of cDNA-AFLP, microarrays, and genechip expression data in Saccharomyces cerevisiae. Genomics 82:606-618.

Salinas-Mondragón, R., Garcidueñas-Piña, C., and Guzmán, P. 1999. Early elicitor induction in members of a novel multigene family coding for highly related RING-H2 proteins in Arabidopsis thaliana. Plant Mol. Biol. 40:579-590

Sarowar, S., Oh, H. W., Cho, H. S., Baek, K. H., Seong, E. S., Joung, Y H., Choi, G. J., Lee, S., and Choi, D. 2007. Capsicum annuum CCR4associated factor CaCAF1 is necessary for plant development and defence response. Plant J. 51:792-802.

Serrano, M., and Guzman, P. 2004. Isolation and gene expression analysis of Arabidopsis thaliana mutants with constitutive expression of ATL2, 
an early elicitor-response RING-H2 zinc-finger gene. Genetics 167:919-929.

Shillingford, C. A. 1978. Climatic factors affecting post-harvest decay of Jamaican bananas. J. Agr. U. Puerto Rico 63:45-49.

Slabaugh, W. R., and Grove, M. D. 1982. Postharvest diseases of bananas and their control. Plant Dis. 66:746-750.

Swiedrych, A., Lorenc-Kukula, K., Skirycz, A., and Szopa, J. 2004. The catecholamine biosynthesis route in potato is affected by stress. Plant Physiol. Biochem. 42:593-600.

Takizawa, M., Goto, A., and Watanabe, Y. 2005. The tobacco ubiquitinactivating enzymes NtE1A and NtE1B are induced by tobacco mosaic virus, wounding and stress hormones. Mol. Cells 19:228-231.

Tornero, P., Conejero, V., and Vera, P. 1996. Primary structure and expression of a pathogen-induced protease (PR-P69) in tomato plants: Similarity of functional domains to subtilisin-like endoproteases. Proc. Natl. Acad. Sci. U.S.A. 93:6332-6337.

Trindade, L. M., Horvath, B. M., van Berloo, R., and Visser, R. G. F. 2004 Analysis of genes differentially expressed during potato tuber life cycle and isolation of their promoter regions. Plant Sci. 166:423-433.

Tsubaki, M., Takeuchi, F., and Nakanishi, N. 2005. Cytochrome b561 protein family: Expanding roles and versatile transmembrane electron transfer abilities as predicted by a new classification system and protein sequence motif analyses. Biochim. Biophys. Acta (BBA) Proteins Proteomics 1753:174-190.

Valette, C., Andary, C., Geiger, J. P., Sarah, J. L., and Nicole, M. 1998 Histochemical and cytochemical investigations of phenols in roots of banana infected by the burrowing nematode Radopholus similis. Phytopathology 88:1141-1148.

Van der Hoorn, R. A. L., and Jones, J. D. G. 2004. The plant proteolytic machinery and its role in defence. Curr. Opin. Plant Biol. 7:400-407.

Van Loon, L. C., Rep, M., and Pieterse, C. M. J. 2006. Significance of inducible defense-related proteins in infected plants. Annu. Rev. Phyto- pathol. 44:135-162.

Venkatesh, B., Hettwer, U., Koopmann, B., and Karlovsky, P. 2005. Conversion of cDNA differential display results (DDRT-PCR) into quantitative transcription profiles. BMC Genomics 6:Art. No. 51.

Verelst, W. i. m., and Asard, H. a. n. 2004. Analysis of an Arabidopsis thaliana protein family, structurally related to cytochromes b 561 and potentially involved in catecholamine biochemistry in plants. J. Plant Physiol. 161:175-181.

Walley, J. W., Coughlan, S., Hudson, M. E., Covington, M. F., Kaspi, R., Banu, G., Harmer, S. L., and Dehesh, K. 2007. Mechanical stress induces biotic and abiotic stress responses via a novel cis-element. PLoS Genet. 3:e172.

Wan, C., and Wilkins, T. 1994. A modified hot borate method significantly enhances the yield of high-quality RNA from cotton (Gossypium hirsutum L.). Anal. Biochem. 223:7-12.

Wuyts, N., De Waele, D., and Swennenj, R. 2006. Extraction and partial characterization of polyphenol oxidase from banana (Musa acuminata Grande naine) roots. Plant Physiol. Biochem. 44:308-314.

Wuyts, N., Lognay, G., Verscheure, M., Marlier, M., De Waele, D., and Swennen, R. 2007. Potential physical and chemical barriers to infection by the burrowing nematode Radopholus similis in roots of susceptible and resistant banana (Musa spp.). Plant Pathol. 56:878-890.

Xia, Y., Suzuki, H., Borevitz, J., Blount, J., Guo, Z., Patel, K., Dixon, R. A., and Lamb, C. 2004. An extracellular aspartic protease functions in Arabidopsis disease resistance signaling. EMBO (Eur. Mol. Biol. Organ.) J. 23:980-988.

Zeng, L.-R., Vega-Sanchez, M. E., Zhu, T., and Wang, G.-L. 2006. Ubiquitination-mediated protein degradation and modification: An emerging theme in plant-microbe interactions. Cell Res. 16:413-426.

Zhang, L. Meakin, H., and Dickinson, M. 2003. Isolation of genes expressed during compatible interactions between leaf rust (Puccinia triticina) and wheat using cDNA-AFLP. Mol. Plant Pathol. 4:469-477. 